\title{
Difficulty in Showing Mosaicism I in the Mother of Three Mongols
}

Parental mosaicism for trisomy-21 is a recognized reason for the birth of mongol children, and the possibility of parental mosaicism may be suspected especially in couples who produce more than one 'regular' mongol. However, in a recent review, Richards (1970) found only 11 documented instances of this occurrence. We wish to describe another woman in whom mosaicism was suspected clinically but was difficult to show by chromosome studies.

\section{Findings}

This family presented for investigation at the Royal Children's Hospital in 1963 because the parents had two mongol children. The family pedigree is shown in the Fig. Chromosome studies were carried out at this time on the children, parents, and relatives as indicated. The two mongol children and the maternal uncle were shown to have regular trisomy-G and all the other relatives studied were normal. The results obtained in the abnormal individuals are shown in the Table.

The mother was short in stature and borderline in intelligence, and her facial appearance and head shape strongly suggested mongolism. A second blood sample and a bone marrow sample were therefore examined in an endeavour to find some trisomic cells. Unfortunately, a skin biopsy failed to grow. Even though mosaicism was not shown, it was considered so likely that the parents were told that the chance of

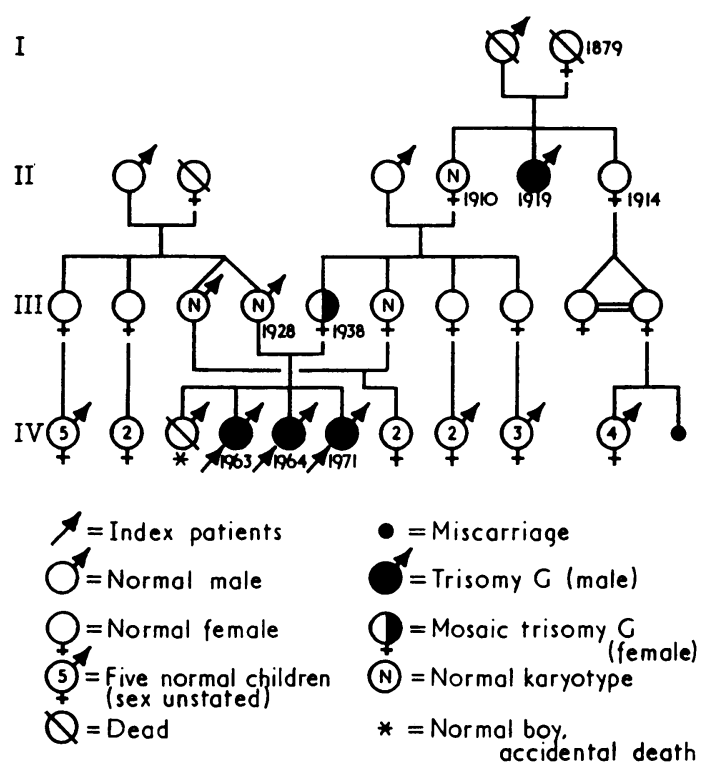

(Years of birth of relevant indjuiduals ore shown)

FIG.-Family pedigree.

having another mongol child could be as high as $\mathbf{5 0} \%$.

In 1970 the family was referred to St. Nicholas Hospital for chromosome study by a clinician who was not aware that studies had already been performed. Leucocyte cultures showed a normal karyotype in the

TABLE

Cytogenetic Data

\begin{tabular}{|c|c|c|c|c|c|c|}
\hline \multirow{2}{*}{ Patient } & \multirow{2}{*}{ Tissue } & \multicolumn{5}{|c|}{ Chromosome Counts } \\
\hline & & 45 & 46 & 47 & Total & Karyotype \\
\hline Mother (III.5) & $\left\{\begin{array}{l}\text { Blood (1964) } \\
\text { Blood (1964) } \\
\text { Bone marrow (1964) } \\
\text { Blood (1970) }\end{array}\right.$ & 1 & $\begin{array}{r}22 \\
30 \\
6 \\
65\end{array}$ & 5 & $\begin{array}{r}22 \\
30 \\
7 \\
70\end{array}$ & $\begin{array}{l}46, X X \\
46, X X / 47, X X, G+\end{array}$ \\
\hline Son (IV.4) & $\left\{\begin{array}{l}\text { Blood (1964) } \\
\text { Blood (1970) }\end{array}\right.$ & & & $\begin{array}{l}15 \\
22\end{array}$ & $\begin{array}{l}15 \\
22\end{array}$ & $47, \mathrm{XY}, \mathrm{G}+$ \\
\hline Son (IV.5) & $\left\{\begin{array}{l}\text { Blood (1964) } \\
\text { Blood (1970) }\end{array}\right.$ & & & $\begin{array}{l}25 \\
22\end{array}$ & $\begin{array}{l}25 \\
22\end{array}$ & $47, X Y, G+$ \\
\hline Mother's maternal uncle (II.4) & Blood (1964) & & & 18 & 18 & $47, X Y, G+$ \\
\hline
\end{tabular}


father and $G$ trisomy in the two mongol children, but revealed 5 cells with 47 chromosomes among 70 cells counted from the mother. In 4 of these cells the extra chromosome was from the $\mathrm{G}$ group, and in the remaining cell it was a C group chromosome. On these results maternal mosaicism with karyotype $46, \mathrm{XX} / 47$, $\mathrm{XX}, \mathrm{G}+$ was diagnosed.

In 1971 the couple elected to have a further child despite the risks involved. A male mongol was born in December 1971. His karyotype has been confirmed as $47, \mathrm{XY}, \mathrm{G}+$.

\section{Discussion}

The difficulty of excluding chromosomal mosaicism has long been recognized, and this family re-emphasizes the need to study large numbers of cells from several tissues of both parents when two or more regular mongols are born to a couple. In this family, studies concentrated on the mother because she showed some clinical features of mongolism, but the initial investigations failed to reveal the mosaicism despite counting 59 cells from two tissues. Fortunately, appropriate genetic advice was still given.

The occurrence of another regular mongol in the family is also of interest, but his mother was 40 years old at his birth, so this may represent a chance occurrence.

\section{Summary}

A case of maternal mosaicism leading to the production of three mongol children is reported. The difficulty of detecting the trisomic cell line and the need to examine large numbers of cells is emphasized.

We thank Drs. Ann Morgan, David Pitt, and Saul Wiener for their assistance with this study; Dr. O. Margaret Garson for the bone marrow studies and confirming the trisomic state of the third child; and the Mental Health Authority for permission to publish this paper.

\section{REFERENCE}

Richards, B. W. (1970). Observations on mosaic parents of mongol propositi. Fournal of Mental Deficiency Research, 14, 342.

\section{G. R. Sutherland, ^ Margaret G. Fitzgerald, and D. M. DANKS \\ Chromosome Laboratory, St. Nicholas Hospital; Cytogenetics Laboratory, Royal Children's Hospital; Genetics Section, Royal Children's Hospital Research Foundation and Department of Genetics, University of Melbourne, Melbourne, Australia.}

^Correspondence to Dr. G. R. Sutherland, Department of Pathology, Royal Hospital for Sick Children, Edinburgh EH9 1LF.

\section{Dizygotic Twins with Down's Syndrome}

It is rare for both members of a twin pair to be concordant for Down's syndrome. The reported incidence of such twins is lower than expected and it is postulated that intrauterine death of one or both members of the pair may often occur (Keay, 1958; Richards, 1971). To our knowledge, when twins have been monozygotic both have always been affected except in one case documented by de Wolff, Schärer, and Lejeune (1962). In contrast, the great majority of dizygotic twins have been discordant for Down's syndrome. A few exceptions have been recorded in twins of the same sex considered to be dizygotic (Russell, 1933; MacKaye, 1936; Jervis, 1943). Röhmer et al. (1970) reported dizygotic twins, the one $47, \mathrm{XX}, 21+$ and clinically mongoloid, the other $46, \mathrm{XX} / 47 \mathrm{XX}, 21+$ and clinically nonmongoloid. We know of only one case of twins of opposite sex, both of whom were considered on clinical grounds alone to have Down's syndrome (Nicholson and Keay, 1957). The purpose of this paper is to put on record dizygotic twins of opposite sex with unequivocal Down's syndrome substantiated by chromosome analyses.

\section{Case Report}

The parents of the twins were not related before marriage. The mother was 39 years and the father 46 years of age when the twins were born.

The mother was one of a family of six, four brothers living and one having died in an accident. She married at the age of 19 years. The father has three brothers and one sister, all of whom are alive and well. Both parents are of average intelligence. No history of Down's syndrome or mental subnormality was discovered on inquiry into the family history.

The mother has had 4 previous pregnancies, 2 of which resulted in normal male infants, the other 2 in first trimester miscarriages. At the time of the birth of the twins, the brothers were aged 20 and 10 years, respectively. They are of normal intellect and have good school records.

The present pregnancy was uneventful but the presence of twins was not suspected until delivery which took place at home. The female twin weighed $2 \cdot 13$ $\mathrm{kg}(4 \mathrm{lb} 11 \mathrm{oz})$ at birth and at the age of 11 months weighed $7.06 \mathrm{~kg}$ (15 lb $9 \mathrm{oz})$. A systolic murmur could be heard over the praecordium compatible with a ventricular septal defect. The male twin weighed $2 \cdot 18 \mathrm{~kg}(4 \mathrm{lb} 13 \mathrm{oz})$ at birth and at 11 months weighed $10 \cdot 8 \mathrm{~kg}(23 \mathrm{lb} 13 \mathrm{oz})$. His cardiovascular system was clinically normal.

No immediate comment about features of Down's syndrome was made during the neonatal period, but a growing doubt as to the normality of the female twin prompted referral, together with her brother, to a 